\title{
A Legal Case on Bid Rigging of Electronic Identity Card Procurement in Indonesia
}

\author{
Eny Budi Sri Haryani ${ }^{1 *}$, Anna Maria Tri Anggraini ${ }^{2}$ \\ ${ }^{1}$ Study Program of Marine Engineering, Institute of Transportation and Logistics Trisakti, Jakarta of Indonesia \\ ${ }^{2}$ Faculty of Law, Trisakti University, Jakarta of Indonesia \\ Corresponding Author*
}

\begin{abstract}
The prohibition of bid rigging is regulated in the Competition Law, which is in accordance with Article 22 of Law No. 5 Year 1999 of Indonesia concerning the Prohibition of Monopolistic Practices and Unfair Business Competition. Whereas the elements of bid rigging include: (1) elements of business actors; (2) elements ofconspiring; (3) elements of other parties; (4) elements of regulating and or determining the winner of the tender; (5) elements of unfair business competition. Because it is stated as a rule of reason behavior, the legal case of bid rigging requires legal proof before it is declared that a violation has occurred. The conspiracy to procure electronic identity card (e-IDCard), which is the object of this research, occurred at the Ministry of Home Affairs of Indonesia, in 20112012 Fiscal Year. The type of research is normative and descriptive, with qualitative analysis using secondary data and drawing conclusions deductively. HowBusiness Competition Supervisory Commission (BCSC) of The Republic Indonesia proves that elements of bid rigging are fulfilled is the main problem of this research. That according to the BCSC's decision No. 03/KPPU-L/2012 horizontal and vertical conspiracy occurred, namely horizontally between Reported Party II (PNRI Consortium) and Reported Party III (Astragraphia Consortium), vertically occurred between Reported Party I (Tender Committee) and Reported Party II (PNRI Consortium), with sanctions in the form of money fine. However, the results of this study stated that the BCSC's decision was not correct legally or wrong decision.
\end{abstract}

Keywords: bid rigging, BCSC, e-IDCard, rule of reason.

\section{INTRODUCTION}

$\mathrm{L}$ aw No. 5 Year 1999 of Indonesia concerning the Prohibition of Monopolistic Practices and Unfair Business Competition (Law No. 5/1999), in Article 22 stipulates the prohibition of bid rigging [12]. Basically, bid rigging not only violates the law as stated in Law No. 5/1999, however, if the tender is a procurement of government goods/services and is detrimental to state finances, it is a serious threat that undermines the performance and authority of the bureaucracy in the government [13]. Bid rigging is a form of unfair cooperation in business, prohibited by law, but is often considered a common thing and must be understood. Not only occurs in the tender process in legal entities of private company, but also in State-Owned Enterprises, Regional Owned Enterprises, in the procurement of government goods/services using the State Budget of Indonesia or Provincial/Regencial Budget [18].
The practice of bid rigging is a conspiracy between officials, the committee for the procurement of goods/services and bidders, namely business actors providing goods/services. Common practices are price mark-ups, winning bid arrangements and other negative behaviors [16]. Strict legal sanctions are urgent, not only administrative sanctions, but also money fines or strict civil sanctions, or criminal sanctions in order to provide a deterrent effect [1].

The procurement of government goods/services, State-Owned Enterprises, Regional Owned Enterprises and the private sector, always goes through a tender process. Bid rigging is the dominant case among cases of unfair business competition. From 2000-2016, the Business Competition Supervisory Commission (BCSC) of The Republic Indonesia has examined 342 cases with 245 tender cases. The total value of the tenders examined is IDR 33.1 Trillion and USD 142.5 Billion [3]. An additional 1 (one) year, in 2000-2017, there were 359 business competition cases and as many as 250 were cases of bid rigging and the rest were non bid rigging. Around $70 \%$ of legal cases at BCSC of Indonesia are bid rigging, which is dominated by the procurement of government goods/services using State Budget of Indonesia or Provincial/Regencial Budget [5]. If it is proven that bid rigging has occurred, the sanctions imposed will still allow the work/project to continue and will not provide a deterrent effect. All parties should understand well the legal provisions and legal sanctions of whatever form, and comply with them [9].

Bid rigging is a prohibited "business conspiracy", is a form of trade cooperation between business actors, to dominate the market for the interests of business actors who conspire, so that business competition becomes unfair [20]. The task of BCSC of Indonesia is to supervise in order to bid rigging does not occur. The task is getting harder because it has to be careful in proving, along with the various modes that are used by persons of violations. Therefore the BCSC of Indonesia in implementing the element of bid rigging is appropriate in accordance with BCSC's Regulation No. 2/2010 on Guidelines for Article 22 of Law of Indonesia No. 5/1999 or not, it is important to research.

The case of conspiracy to tender for electronic identity cards (e-IDCard) that occurred at the Ministry of Home Affairs of Indonesia in 2011-2012 became a case that was decided by the BCSC of Indonesia and was controversial, which is very good 
to be investigated. So that in this study, the e-IDCard case was used as a case study, with the main issue raised was "whether the BCSC's Decision Number 03/KPPU-L/2012 concerning Alleged Bid Rigging in the Procurement of e-IDCard inThe Directorate General of Population and Civil Registration, Ministry of Home Affairs of Indonesia for Fiscal Years 2011 and 2012, has correctly applied the elements of Article 22 of Law of Indonesia No. 5/1999?".

With this subject matter, the research was conducted with the aim of providing an overview of the application of the elements of Article 22 of Law of Indonesia No. 5/1999 by the $\mathrm{BCSC}$ in deciding the occurrence of bid rigging in the procurement of e-IDCard at the Directorate General of Population and Civil Registration, Ministry of Home Affairs of Indonesia for Fiscal Years 2011 and 2012. So that the research results can provide benefits and knowledge to the public, in order to they always carry out fair business competition and do not commit bid rigging. Because bid rigging is very detrimental to the community and violates business competition law, it is also a rule of reason behavior that must be proven to have occurred [2]. Therefore, the main problem can be described and the evidence can be clearly described, this research was conducted with the title "A Legal Case on Bid Rigging of Electronic Identity Card Procurement in Indonesia".

\section{RESEARCH METODOLOGY}

This research is a normative legal research, which is conducted by examining library materials or secondary data, and this research conducted at the month of November to December 2020. The nature of the research is descriptive, with the results describing the solutions to the problems raised in the research, so that an overview of the principles of business competition law related to the BCSC's decision related to bid rigging in the procurement of e-IDCard can be obtained [17].

The object of this research is the decision of the bid rigging on the procurement of e-IDCard in 2011 and 2012, namely the BCSC's Decision Number 03/KPPU-L/2012. Then the data used in this study is secondary data obtained through library research, including official documents, books, related research results and so on, which include: (1) primary legal materials, namely legal materials that are binding, including Law of Indonesia No. 5/1999, Gowernment Regulatioins related to the procurement of government goods/services, BCSC Regulation; (2) secondary legal materials, namely supporting legal materials consisting of books, journals, research reports, scientific articles, seminar materials, workshops, which are related to the main issues in this research [17].

The data collection technique was carried out by literature study to obtain secondary data [15], which was carried out in several places, as well as online access via the internet network. Data analysis was carried out qualitatively [17] and conclusions were drawn using a deductive approach [10]. The conclusions are drawn to answer the main problem, which then produces suggestions for the tender conspiracy case in this study.

\section{RESULT}

\section{A. Object and case Chronology}

The object of the case is a tender for the procurement of eIDCard in 2011-2012 with the State Buged of Indonesia, Fiscal YearBudget of the Directorate General of Population and Civil Registration, Ministry of Home Affairs of Indonesia with a value of IDR 5,951,886,009.000,- (Five Trillion Nine Hundred Fifty One Billion Eight Hundred Eighty Six Million Nine Thousand of Indonesian Rupiah). The chronology of the case begins with a report coming to BCSC in the form of an alleged violation of Law of Indonesia No. 5/1999 regarding the procurement of e-IDCard, which is clearly the absolute competence of the BCSC [6].

After the investigation, there is initial evidence of violation of Article 22 of Law of Indonesia No. 5/1999, the existence of unfair business competition. After the investigation, a Report of Alleged Violations was made with Commission Determination No. 21/KPPU/Pen/III/2012 dated March 30, 2012 concerning Preliminary Examination of Case No. 03/KPPU-L/2012. Subsequently issued Commission Decree No. 114.3/KPPU/Kep/III/2012 dated March 30, 2012 concerning the Assignment of Commission Members as Commission Council on the Preliminary Examination of Case Number 03/KPPU-L/2012. Then an intensive Preliminary Examination and Commission Assembly Session was carried out with the reported parties, namely Reported Party I, the Tender Committee for the Procurement of e-IDCard, Reported Party II the PNRI Consortium, Reported Party III Astragraphia Company, Reported Party IV Kwarsa Hexagon Company, Reported Party V Trisakti Mustika Graphika Company, Reported VI Sumber Cakung Company [6].

\section{B. Case Position}

In case BCSC's Decision Number 03/KPPU-L/2012, the Reported Parties were determined to have violated Article 22 of Law No.5/1999, namely horizontal conspiracy by fellow bidders in the form of similarity in technical proposal methods, typing errors, and cooperation in the number of products offered. In addition, the vertical conspiracy carried out by the Reported Party I by facilitating the Reported Party II (the PNRI Consortium) became the winner of the Tender [6].

BCSC's evidence related to elements of violation of Article 22 of Law of Indonesia No. 5/1999 [6]:

1. Elements of business actors. Business actors are regulated in Article 1 number 5 of Law of Indonesia No. 5/1999 and what is meant by business actors in this case are the PNRI Consortium, Astragraphia Company, Kwarsa Hexagon Company, Trisakti Mustika Graphics Company, Sumber Cakung Company, so the elements of business actors are fulfilled; 
2. Elements of conspiracy. According to the horizontal conspiracy analysis, that the conspiracy was carried out by Reported Party II (PNRI Consortium) and Reported Party III (Astragraphia Company). According to the vertical conspiracy analysis, that the conspiracy was carried out by Reported Party I, Reported Party II and Reported Party III. The two conspiracies were proven in post bidding actions and the existence of informal meetings outside the official schedule, so the element of conspiring was fulfilled.

3. Elements of the other party. The other party in this case is the Reported Party I (Tender Committee), thus the elements of the other party are fulfilled.

4. Elements of arranging and or determining the winner of the tender. Determination of the winner of the tender through the facilitation of the Reported Party II as the winner of the tender as described in the vertical conspiracy analysis, so that the elements of regulating and or determining the winner of the tender are fulfilled.

5. Elements can lead to unfair business competition. The Reported Party I facilitated a horizontal conspiracy between the Reported Party II and the Reported Party III, which was an act that hindered business competition. So the elements that can lead to unfair business competition are met.

\section{Verdict}

Based on the facts, assessment, analysis and legal considerations, the BCSC's decision No. 03/KPPU-L/2012 as follows [6]:

1. Reported Party I, Reported Party II, Reported Party III, were legally and convincingly proven to have violated Article 22 of Law no. 5/1999;

2. Reported Party IV, Reported Party V, and Reported Party VI were not proven to have violated Article 22 of Law no. 5/1999;

3. Reported Party II, pays a fine of IDR 20,000,000,000.00 (Twenty Billion Indonesian Rupiah) which must be deposited into the State Treasury;

4. Reported Party III, pays a fine of IDR 4,000,000,000.00 (Four Billion of Indonesian Rupiah) which must be deposited into the State Treasury.

\section{DISCUSSION}

A. Forms of Conspiracy According to Article 22 of Law of Indonesia No. 5/1999

The Commission Council determined the existence of horizontal conspiracy based on the evidence indicating horizontal conspiracy carried out by Reported Party II and Reported Party III as follows [6]:
1. The similarity of including chip solutions and strategies in the method of technical proposal from Reported Party II and Reported Party III;

2. The similarity of typographical errors in the administrative and technical documents of book IV of the Reported Party III and the technical documents of the Reported Party II;

3. Regarding the products offered by Reported Party II and Reported Party III.

The Commission Council has also determined the occurrence of vertical conspiracy as follows [6]:

1. Regarding the requirements of ISO 9001 and 14001, the requirements of the Reported Party I were not met by the Reported Party II and the Reported Party III, but were still passed;

2. The behavior of the Reported Party I which did not respond properly to the objection of the Telkom Consortium stating that the Signature specification was not ISO 9001 and 14001, however Reported Party I replied that the Reported Party II and Reported Party III had ISO 9001 and 14001;

From the data and indications mentioned above, the author is of the opinion that there is a strong indication that the bid rigging actually occurred between the Reported Party II and the Reported Party III with another party (Reported I), but none of the witnesses at the trial stated that they knew the conspiracy occurred [9]. Likewise, other evidence was not able to be presented in court, so the proof of this case was weak, because it was not supported by 2 (two) valid pieces of evidenceas set out in The Criminal Code of Indonesia [19].

\section{B. BCSC's Evidence Mechanism}

\section{Evidence}

Evidence in bid rigging cases is regulated in Article 42 of Law of Indonesia No. 5/1999, that the evidence is not only in the form of witness statements, but can also come from expert testimony, letters and or documents, instructions, statements of business actors [11]. Proof at trial must be with sufficient evidence, at least 2 (two) valid pieces of evidence [19].

The witnesses presented by the BCSC at the trial were: (a) Joni Santoso, Chairman of the Telkom Consortium, testified that the Topaz brand Signature Pad product SignatureGem TM LCD 1x5 did not have ISO 9001 and 14001; (b) Winata Cahyadi, Director of Lintas Bumi Lestari Company, which objected to the announcement of the tender winner; (c) Japar Hendra, Budi Prasetyo and Hari Wongsooentoro as Chairman of the Transtel Universal Consortium, who did not pass the aanwijzing; (d) Head of the Mega Global Jaya Consortium Grafia Cipta and Head of the Murakabi Sejahtera Consortium; (e) Yimmy Iskandar Tedjo Susilo, from Java Trade Company, who testified that he had assisted in the preparation of the Murakabi Consortium documents; (f) Husni Fahmi as the head of the Information Technology technical team at the 
Directorate General of Civil and Civil Registration of the Ministry of Home Affairs of Indonesia along with Meidy Layooari, Kristian Ibrahim Moekmin, Gembong Wibowanto, as a team member [6]. The witnesses presented were in accordance with the requirements and criteria for witnesses in Article 72 of BCSC's Regulation No. 1/2010 [7] and Articles 46 and 50 of BCSC's Regulation No. 1/2019 [4]. The information given is quite varied, but does not provide evidence that the conspiracy actually occurred, all of which are only indications/instructions [9].

Expert testimony from Setya Budi Arijanta, as the Head of the Sub-Directorate of the Government Goods and Services Procurement Policy Institution (GGSPPI) and the GGSPPI Assistance Team, that the violation of Presidential Regulation No. 54/2010 did not happen, due to objections to the tender processstill in rebuttal and not over yet [14]. However, according to the authors's opinion, the person concerned is not an expert category as stipulated in Article 75 of BCSC's Regulation No. 1/2010 or Article 52 of BCSC Regulation No. $1 / 2019$ [6]. The expert testimony is also not used to prove that the elements of the tender conspiracy have been proven/fulfilled [9].

Then for letters and/or documents for proof at the Commission Council trial in the form of: (a) 144 documents, which include bundles of technical documents for tender participants, and bundles of administrative documents for the administration of tenders; and documents related to laws and regulations, as well as determination of tender winners and work orders; (b) 22 documents, including documents attached to the evidence of the Reported Party I, and related technical evidences; (c) 3 bundles of documents, namely a chronological bundle of tender stages, a bundle of technical proposals for implementation methodology, a bundle of photocopies of ISO certificates; (d) 13 documents, namely technical documents, annual reports and supporting documents; (e) 2 documents, namely a copy of the deed of consortium agreement and a copy of the winning bidder [6]. The evidence of the letter and or document mentioned above is a letter or document in the criteria that can be used for proof [7], but in the opinion of the author, that at trial the evidence of this letter/document cannot be explained as valid evidence because it is not sharp in its analysis [9].

\section{Elemental Proof}

It is very important to prove that the elements of the bid rigging have been fulfilled. BCSC Regulation No. 2/2010 on Guidelines for Article 22 of Law of Indonesia Number 5 of 1999, that elements of bid rigging consist of: (1) elements of business actors; (2) elements of conspiring; (3) elements of other parties; (4) elements of regulating and or determining the winner of the tender; (5) elements of unfair business competition [8]. The proof analysis of the five elements is described as follows:

\section{a. Elements of Business Actors}

The elements of business actors in this case are:

1) The PNRI Consortium, hereinafter referred to as the Reported Party II, which consists of: Public Company PNRI, Sucofindo Company, Len Industri Company, Sandipala Arthaputra Company, and Quadra Solutions Company;

2) Astragraphia Company, hereinafter referred to as Reported Party III;

3) Kwarsa Hexagon Company, hereinafter referred to as Reported Party IV;

4) Trisakti Mustika Grafika Company, hereinafter referred to as Reported Party V;

5) Sumber Cakung Company, hereinafter referred to as Reported Party VI;

Therefore, according to the BCSC's Decision, the elements of business actors are fulfilled, which consists of more than 2 business actors [6]. However, the evidence at the trial is very weak, because it must be proven that they have a conspiracy agreement, either openly or secretly. Facts at trial cannot be shown by 2 (two) valid pieces of evidence, because they are only based on indications or assumptions [9].

\section{b. Elements of Conspiracy}

In the BCSC's Decision, it is explained that horizontal conspiracy occurred, which is indicated by indications of conspiracy carried out by the Reported Party II (PNRI Consortium) and the Reported Party III (Astragraphia Company), so that it is considered to fulfill the element of conspiring with the existence of "cooperation between two or more parties, which explicitly openly or secretly take action to adjust the document in the form of setting the number of products offered [6]. Unfortunately, the indications of post bidding action, namely holding informal meetings outside the official schedule, were not carefully proven by BCSC with sufficient evidence [9].

\section{c. Elements of the Other Party}

In accordance with the Guidelines Article 22, what is meant by elements of other parties are parties, both vertically and/or horizontally, who are involved in bid rigging. This involvement can be in the position of business actors as implementation of the tender. Whereas according to the BCSC's decision, the other party in this case is the Reported Party I (Tender Committee), because it is another legal subject involved in the implementation of the tender [6]. However, the fact is that the indications stated by the BCSC are not supported by sufficient evidence, that there are no witnesses and other evidence to support the analysis [9].

\section{d. Elements of Organizing and or Determining Tender Winners}

In this case, the determination of the tender winner is carried out by facilitating the Reported Party II as the winner of the Tender as described in the Vertical Conspiracy Analysis. 
Therefore, according to BCSC, the element of regulating and/or determining the tender winner has occurred [6]. Meanwhile, in court there was not enough evidence, so the BCSC's decision was very weak [9].

\section{e. Elements Can Lead to Unfair Business Competition}

The action of the Reported Party I which facilitated the occurrence of horizontal conspiracy by the Reported Party II and the Reported Party III was an act that hindered business competition. Thus, unfair business competition has occurred, according to the BCSC's decision [6]. In this case, that the indication is also not supported by sufficient evidence, so the evidence is very weak [9].

\section{CONCLUSION AND RECOMMENDATION}

\section{A. Conclusion}

From this research, the following conclusions can be drawn:

1. According to BCSC's Decision No. 03/KPPU-L/2012 there has been a horizontal and vertical conspiracy, with the elements fulfilled in accordance with Article 22 of Law of Indonesia No. 5/1999, with the business actors involved being Reported Party II (PNRI Consortium) and Reported Party III (Astragraphia Consortium), and the other party involved is Reported Party I (Tender Committee). Reported Party II was given a fine of IDR 20,000,000,000.00 (Twenty Billion of Indonesian Rupiah) and the Reported Party III is IDR 4,000,000,000.00 (Four Billion of Indonesian Rupiah);

2. Based on BCSC's Decision No. 03/KPPU-L/2012, according to point 1 , the author is of the opinion that the BCSC's decision is not correct, because:

a. The evidence in court against the elements of bid rigging in Article 22 of Law of Indonesia No. 5/1999 is not fulfilled with sufficient evidence. Although there are actually indications of horizontal and vertical conspiracy, the elements of bid rigging are clearly visible;

b. The process of proving at trial is carried out through witness statements, letters or documents from the bidding process and administration, expert statements from Government Goods and Services Procurement Policy Institution (GGSPPI) staff, instructions and statements of the reported party. Unfortunately, the evidence is very weak, the key witnesses were not presented in the trial, so there was not a single witness who claimed to know that the tender conspiracy really existed. The Business Competition Supervisory Commission(BCSC) of Indonesiawas unable to prove with sufficient evidence in accordance with Article 183 of the Criminal Code of Indonesia, or in accordance with Article 1 Number 13 of BCSC's Regulation No. $1 / 2019$, sufficient evidence is the fulfillment of at least 2 (two) valid pieces of evidence.

\section{B. Recommendation}

Based on the conclusions above, some recommendation are:

\section{For BCSC of Indonesia:}

As a supervisory agency that decides cases of bid rigging, so that in proving the alleged violation of Article 22 of Law of Indonesia No. 5/1999 can be accompanied by strong (valid) evidence, at least 2 (two) pieces of evidence that are legally valid. This is to provide a sense of justice for the litigants, so that case decisions are not only based on assumptions, without transparency of evidence.

\section{Amendment to Regulations:}

Improvement of laws and regulations is very important, in order to ensure the speed and accuracy of deciding cases at the BCSC. So there is no need for assumptions and interpretations in deciding cases, because there is no need for proof. This can be done by changing from the rule of reason to persee illegal which does not need proof, so there is no need for a long and easily canceled judicial process.

\section{ACKNOWLEDGMENTS}

The authors would like to acknowledge The Business Competition Supervisory Commission (BCSC) of The Republic Indonesiaand all staff, as well as the people who consern to business competitionand want fair business competition to occur.Thanks are also conveyed to the Faculty of Law, Trisakti University, Jakarta-Indonesia and the people who has supported during the research implementation.

\section{REFERENCES}

[1] Asmah, A. (2019). Implementation of Final Sanctions on the Case of National Road Tender Collaboration. Judicial Journal, 12(2), 197-214.

[2] Anggraini, A. M. (2003). Prohibition of Monopolistic Practices and Unfair Competition Perse Illegal or Rule of Reason. Faculty of Law, University of Indonesia.

[3] Business Competition Supervisory Commission (BCSC) of The Republic Indonesia. (2020). The Strategic Plan of the Commission of Supervisory and Business Competition of Indonesia for the Year 2020-2024.

[4] Business Competition Supervisory Commission (BCSC) of The Republic Indonesia. (2019). Regulation No. 1 Concerning Procedures for Handling Monopolistic Practices and Unfair Business Competition in Indonesia.

[5] Business Competition Supervisory Commission (BCSC) of The Republic Indonesia. (2019). Annual Report.

[6] Business Competition Supervisory Commission (BCSC) of The Republic Indonesia's Decision Number 03/KPPU-L/2012 Regarding Alleged Violations of Article 22 of Law on Indonesia Number 5 of 1999 Relating to Tenders for Application of National NIK-Based Identity Cards (e-IDCard) 2011 to 2012 With Sources of State Budget of Indonesia, Funds DIPA Directorate General of Population and Civil Registration of the Ministry of Home Affairs of Indonesia for Fiscal Year 2011 and 2012.

[7] Business Competition Supervisory Commission (BCSC) of The Republic Indonesia. (2010). Regulation No. 1 Concerning Procedures for Handling Cases.

[8] Business Competition Supervisory Commission (BCSC) of The Republic Indonesia. (2010). Regulation No. 2 Concerning Guidelines for Article 22 of Law of Indonesia Number 5 of 1999 Concerning the Prohibition of Bid Rigging. 
[9] Haryani, E. B. S. (2021).Bid Rigging in the Procurement of Electronic Identity Cards for Fiscal Years 2011 and 2012: A Study of the Supreme Court Decision Number 55K/Pdt.Sus-KPPU/2014. Jakarta: Undergraduate Thesis Program, Faculty of Law, Trisakti University.

[10] Hanson, S. (Ed.). (2018). Legal method and reasoning. Routledge.

[11] Kumalasari, D. M. S. (2017). Business competition law: a study of the concept of proof of a price fixing agreement in business competition. Setara Press.

[12] Law of Indonesia Number 5 of 1999 Concerning the Prohibition of Monopolistic Practices and Unfair Business Competition.

[13] Maheswari, A. A. (2020). Limitation, Authority and Involvement of KPPU in Tender Conspiracy Cases according to Business Competition Law. Jurist-Diction, 3(5), 1581-1596.

[14] Presidential Regulation of the Republic of Indonesia Number 54 of 2010 Concerning Government Procurement of Goods/Services.

[15] Singleton, R., Bruce, C., Straits, M. Straits, M., and Ronald J. M. (2018).Approaches to Social Research. New York: Oxford University Press.
[16] Sutedi, A. (2019). Legal Aspects of Procurement of Goods and Services and Various Problems, Second Edition, Third Printing. Jakarta: Sinar Graphic.

[17] Soekanto, S. (2015). Introduction to Legal Studies.Jakarta: University of Indonesia (UI-Press) Publisher.

[18] Sirait, R. A. M. (2020). Prohibition of collaboration in tender based on Law number 5 of 1999 concerning prohibition of monopoly practices and unfair business competition. Tanjungpura Law Journal, 4(2), 178-190.

[19] The Criminal Code of Indonesia. (1918). Government of Indonesia.

[20] Zihaningrum, A., \& Munawar, K. (2016). Legal Enforcement of Bid Rigging Based on Law Number 5 of 1999 Concerning the Prohibition of Monopolistic Practices and Unfair Business Competition.Journal of Private Law, Faculty of Law Sebelas Maret University, Vol. IV, No. 1. 